\section{CHARAKTERYSTYKA DOROBKU NAUKOWEGO, ORGANIZACYJNEGO I DYDAKTYCZNEGO PROFESORA ANTONIEGO JACKOWSKIEGO}

\section{PROFESSOR ANTONI JACKOWSKI: RESEARCHER, ORGANISER AND TEACHER}

\section{1. ŻYCIORYS NAUKOWY}

Profesor Antoni Jackowski urodził się 1 czerwca 1935 r. w Brugge (Belgia). Studia geograficzne odbył na Wydziale Biologii i Nauk o Ziemi Uniwersytetu Jagiellońskiego w latach 1954-1959. Ukończył je z wyróżnieniem, uzyskując stopien magistra geografii w zakresie geografii ekonomicznej. Po studiach w 1960 r. podjął pracę w Bibliotece Jagiellonskiej. Poczatkowo $\mathrm{w}$ formie prac zleconych, a od 1961 r. jako pracownik etatowy w stopniu bibliotekarza służby bibliotecznej. Następnie, w latach 1967-1972, pracował w Pracowni Krakowskiej Zakładu Zagospodarowania Turystycznego GKKFiT jako starszy projektant. W 1971 r. w Instytucie Geografii Uniwersytetu Jagiellońskiego obronił pracę doktorska pt. Turystykajako element gospodarki Podhala. Studium z geografii turyzmu i uzyskał stopień doktora nauk geograficznych. Od 1 października 1972 r. pracuje nieprzerwanie w Instytucie Geografii UJ (od 2000 r. Instytut Geografii i Gospodarki Przestrzennej UJ). Stopień doktora habilitowanego nauk geograficznych w zakresie geografii turyzmu uzyskał w 1983 r. na podstawie rozprawy habilitacyjnej pt. Typologia funkcjonalna miejscowości turystycznych (na przykładzie województwa nowosądeckiego). W październiku 1984 r. został powołany na stanowisko docenta, a tytuł profesora nauk przyrodniczych otrzymal w marcu 1992 r. W dniu 26 czerwca 1991 r. Rektor Uniwersytetu Jagiellońskiego powołał Go na stanowisko profesora nadzwyczajnego. Z dniem 1 kwietnia 1998 r. Minister Edukacji Narodowej nadał mu tytuł profesora zwyczajnego.

\section{ACADEMIC BIOGRAPHY}

Professor Antoni Jackowski was born on 1 June 1935 in Brugge/Bruges (Belgium). From 1954-1959 he studied geography in the Biology and Earth Sciences Department of the Jagiellonian University, Krakow graduating with an MA (with distinction) in the field of economic geography. In 1960 he started work part time at the Jagiellonian Library and from 1961 he was employed as a full-time librarian. From 19671972 he worked at the Krakow Tourism Development Department as a senior planner. In 1971 at the Jagiellonian University Institute of Geography he defended his doctoral thesis Tourism as an Element of the Podhale Economy: a study in the Geography of Tourism. Since 1 Oct 1972 he has been working at the Institute of Geography at the Jagiellonian University (in 2000 changed into the Institute of Geography and Spatial Economy). His habilitation thesis A Functional Typology of Tourism Destinations: a case study of Nowosadeckie Województwo was submitted in 1983, in 1984 he was appointed docent ('associate' professor), and in March 1992 a professor of natural sciences. On 26 June 1991 the Rector of the Jagiellonian University nominated him 'university' professor (nadzwyczajny), and on 1 April 1998 the Minister of Education nominated him 'full' professor (zwyczajny). 


\section{DZIAŁALNOŚĆ NAUKOWO-BADAWCZA}

W początkowym okresie działalności naukowej badania Prof. A. Jackowskiego skupiały się wokół problematyki geografii przemysłu. Z tego zakresu opublikował fragmenty swej pracy magisterskiej pt. Przemyst szklarski w Polsce (1961). Potem Jego zainteresowania zaczęy się koncentrować na zagadnieniach zwiazzanych $\mathrm{z}$ geografia turyzmu. Wykorzystując swa prace $\mathrm{W}$ Bibliotece Jagiellońskiej, pod koniec 1962 r. przystapił do opracowania bibliografii turystyki polskiej, której wykonanie zlecił $\mathrm{Mu}$ Departament Zagospodarowania Turystycznego GKKFiT. Bibliografia turystyki polskiej została opublikowana w latach 1968-1973 i objęła siedem tomów. Ponadto ukazało się kilka skróconych jej wersji przeznaczonych do celów dydaktycznych. Podejmując się tego opracowania prof. A. Jackowski nie dysponował żadnymi wzorami krajowymi ani zagranicznymi. Niektóre części tej publikacji, ze względu na zakres i metody niezbędnych badań zwiazanych $z$ jej przygotowaniem, recenzenci określali jako autentyczny dorobek naukowy. W pewnym sensie było to wówczas dzieło pionierskie, bardzo ważne dla rozwoju badań nad turystyką. Bibliografia stała się też wzorem i podstawą do sporzadzania bibliografii turystycznych przez inne osoby i instytucje.

W okresie pracy w Zakładzie Zagospodarowania Turystycznego GKKFiT zakres studiów A. Jackowskiego, dotyczących problematyki turystycznej, uległ znacznemu poszerzeniu, głównie poprzez aktywny udział w opracowaniach planistycznych. Podją również badania o charakterze metodycznym, dotyczące ekonomicznych konsekwencji rozwoju turystyki w regionie. Problematyce tej poświęcił wspomnianą już rozprawę doktorska, a także kilka innych publikacji. Prace $z$ tego zakresu ukazywały rolę turystyki jako czynnika rozwoju gospodarczego regionów i miejscowości, inspirowały też podjęcie podobnych badań $\mathrm{w}$ innych ośrodkach geograficznych. Powołania na nie odnaleźć można w zagranicznej literaturze przedmiotu. W tym okresie, dzięki ścisłej współpracy z Głównym Urzędem Statystycznym, opracował wspólnie z J.War-

\section{RESEARCHER}

Initially, Prof. Jackowski focused on issues in industrial geography and he published part of his MA thesis as The Glass Industry in Poland (1961) but later his interests turned towards issues in the geography of tourism. Taking advantage of his work at the Jagiellonian Library in 1962 he started work on a bibliography of Polish tourism as requested by the Tourism Development Department. The Bibliography of Polish Tourism was published between 1968 and 1973 in seven volumes and several abridged versions were published for teaching purposes. When starting this particular work he did not follow Polish or foreign models and some parts were described as truly original research by its reviewers due to the range and the research methods used. It was a pioneering piece of work at the time and extremely useful for further research in tourism with the Bibliography becoming a model for other researchers and institutions.

During the time Prof. Jackowski worked at the Tourism Development Department the scope of his studies in tourism widened considerably, mainly due to his active participation in planning. He started methodological research into the economic consequences of tourism development, issues discussed in his doctoral thesis Tourism as an Element of the Podhale Economy: a study in the Geography of Tourism as well as in several other publications. They presented the role of tourism as an economic development factor both regionally and at individual destinations, as well as encouraging similar research at other geographical centres. They were quoted in foreign literature on the subject. In that period, in close co-operation with the Main Statistical Office, Prof. Jackowski, with Profs Warszyńska and Bukowski, devised statistical methods for use in the study of tourism. 
szyńska i J. Bukowskim propozycję metodyczna badan statystycznych w dziedzinie turystyki.

Po rozpoczęciu pracy w Instytucie Geografii Uniwersytetu Jagiellonskiego coraz więcej miejsca w publikacjach Profesora zaczęły zajmować studia o charakterze teoretyczno-metodycznym. Odnosiły się one zarówno do teorii geografii turyzmu, jako młodej jeszcze wówczas dyscypliny geograficznej, jak i konkretnych rozwiazan metodycznych. Zagadnienia teoretyczne najobszerniej zostały ujęte w podreccniku Podstawy geografii turyzmu (współaut.: J. Warszyńska) ${ }^{1}$, ponadto $\mathrm{w}$ pracach o tematyce terminologicznej. To właśnie prof. Antoni Jackowski wspólnie $z$ prof. Jadwiga Warszyńska uznawani sa powszechnie za twórców powojennej polskiej szkoły geografii turyzmu. Ważny nurt w działalności naukowej Profesora w tamtym okresie stanowily studia metodologiczne. Były to przede wszystkim syntezy zmierzajace do opracowania typologii przestrzennej $\mathrm{z}$ zastosowaniem metod statystycznych, głównie koncentracji i taksonomii numerycznej. Prace te dotyczyły zagadnień metodologicznych typologii miejscowości turystycznych. Temu problemowi poświęcona była również rozprawa habilitacyjna pt. Typologia funkcjonalna miejscowości turystycznych (na przykładzie województwa nowosadeckiego) ${ }^{2}$, która zawierała propozycje metodyczne procedury typolgicznej dla tego typu jednostek osadniczych. Byto to pierwsze w Polsce opracowanie, w którym zaprezentowano w sposób naukowy różnorodność funkcjonalną miejscowości turystycznych. Wydzielone w rozprawie typy funkcjonalne sa zbliżone do znanej klasyfikacji Wiliam-Ollsona, co świadczy o pokrewieństwie metodologicznym klasyfikacji funkcjonalnej miast $\mathrm{z}$ klasyfikacja funkcjonalna osadnictwa turystycznego. Prace dotyczace typologii miejscowości turystycznych były cytowane w zagranicznej literaturze geograficznej, przy czym najobszerniej w podręczniku D. Pearce'a pt. Tourism today: a geographical analysis (New York 1987).

Prof. A. Jackowski w latach 70. podją też studia zmierzajace do nakreślenia tradycji badań z zakresu geografii turyzmu w Polsce oraz historii turystyki. Rozszerzoną wersję swoich dociekan naukowych
Having started work at the Jagiellonian University Institute of Geography, Prof. Jackowski published many more theoretical and methodological studies concerning both the new academic discipline of tourism geography and methodological solutions. Theoretical issues were most widely discussed in the textbook The Fundamentals of the Geography of Tourism (written jointly with Prof. Warszyńska) ${ }^{1}$ and in works devoted to terminology. It is Prof. Antoni Jackowski and Prof. Jadwiga Warszyńska who are commonly regarded as the creators of the Polish post-war school of tourism geography.

Methodological studies were an important part of his academic activity aiming at establishing a spatial typology by means of statistical techniques, mainly numerical and taxonomic. His works concerned methodological issues in the typology of tourist destinations reflected in the topic of his habilitation thesis A Functional Typology of Tourism Destinations: a case study of Nowosadeckie Województwo2 which included methodological suggestions regarding the typological procedure of such settlement units. It was the first publication in Poland where the functional diversity of tourism destinations had been treated in an academic way. The functional types discussed are similar to those in the popular classification by William-Olson demonstrating the methodological affinity between functional classifications of urban areas and tourism destinations. His work on the typology of tourism was quoted in the foreign geographical literature, most widely in Pearce's textbook Tourism Today: a geographical analysis (New York 1987).

In the 1970s Prof. Jackowski undertook studies which aimed at presenting traditions in approaches to the geography of tourism in Poland as well as the history of tourism. An extended version of his thinking is presented in the textbook The Fundamentals of the Geography of Tourism (written in collabora- 
przedstawił w podręczniku Podstawy geografii turyzmu (współaut.: J. Warszyńska). W tym nurcie mieści się również póżniejsza jego praca zwiazana $z$ dziejami Studium Turyzmu UJ, a także redakcja całego tomu pt. Studium Turyzmu Uniwersytetu Jagiellońskiego (1936-1939) (Kraków 1992).

Po uzyskaniu stopnia doktora habilitowanego zainteresowania naukowe Prof. A. Jackowskiego skoncentrowały się wokól zagadnień zwiazanych $\mathrm{z}$ geografia religii, a zwłaszcza $z$ migracjami pielgrzymkowymi - zarówno w skali światowej, jak krajowej. Badania takie nie stanowiły przedtem przedmiotu odrębnych studiôw w polskiej geografii. Skromna była również w tym zakresie światowa literatura geograficzna i religioznawcza. W swoich pracach przedstawił swój punkt widzenia na istotę geografii religii i specyfikę badan tej dyscypliny nauk geograficznych. Interesowały go głównie aspekty historyczno-przestrzenne migracji pielgrzymkowych oraz ich wpływ na przekształcenia fizjonomiczne i społeczno-ekonomiczne zarówno poszczególnych ośrodków kultu religijnego, jak i całych regionów, a nawet krajów. Podjęte badania stanowily zatem próbę uzupełnienia tej luki w literaturze swiatowej. W publikowanych artykułach zarysował główne problemy badawcze geografii pielgrzymek na przykładzie Polski oraz krajów islamu. Prace te były cytowane w szeregu publikacji zagranicznych zwiazanych z geografia religii. Był zaproszony do przedstawienia wyników swych badań dotyczących migracji pielgrzymkowych w Polsce w specjalnej edycji „Annals of Tourism Research" (vol. 19, no 1, 1992), periodyku wydawanego przez Pergamon Press Inc. (USA).

Syntezę studiów w tej dziedzinie stanowia dwie obszerne monografie: Zarys geografii pielgrzymek (Kraków 1991) oraz Pielgrzymki $i$ turystyka religïna $w$ Polsce (Warszawa 1991) ${ }^{3}$. W pierwszej przedstawiono najważniejsze zagadnienia zwiazane $z$ pielgrzymkami we współczesnych religiach świata. Zaprezentowano je w ujęciu historycznym i przestrzennym na tle podstawowych założeń danej wiary oraz wynikajacych $z$ nich nakazów religijnych inspirujących decyzję o podjęciu pielgrzymki. Było to pierwsze w literaturze swiatowej opracowa- tion with Prof. Warszyńska). Similar issues are discussed in his later work on the history of the pre-war Tourism Research Unit (studium) at the Jagiellonian University which included his editorship of The Tourism Research Unit at the Jagiellonian University (19361939) (Kraków 1992).

After his habilitation he became interested in the geography of religion, and especially in pilgrimage on both global and national scales. This type of research had not been conducted independently before in Polish geography while the geographical and religious literature on this theme in other countries was also scarce. He presented his view of the geography of religion stressing the historical and spatial aspects of pilgrimage and its effect on the structure and socio-economic changes of individual religious sites, regions or even countries. His research was an attempt to fill this gap in the literature and in his articles he outlined the main research areas of pilgrimage geography by using examples from Poland and Islamic countries. These publications have been widely quoted in foreign literature concerning the geography of religion. He was invited to present the results of his research into pilgrimage in Poland in a special edition of the Annals of Tourism Research (vol. 19, no 1, 1991), a journal published by Pergamon Press Inc. (USA).

His work in this particular area is collected in two large monographs: An Outline of Pilgrimage Geography (Kraków 1991) and Pilgrimage and Religious Tourism in Poland (Warsaw 1991) ${ }^{3}$. The first presents the most important issues concerning pilgrimage in contemporary religion, shown from historical and spatial perspectives, in relation to the basic principles of a given faith and the religious imperatives inspiring them. It was the first geographical publication of this kind. The second monograph is a detailed study of pilgrimage in Poland in a cultural and socioeconomic context. Both publications were new in Polish geography and in 
nie geograficzne o takim charakterze. Druga monografia stanowi szczególowe studium migracji pielgrzymkowych $\mathrm{w}$ naszym kraju w kontekście uwarunkowań kulturowych i społeczno-ekonomicznych. Obie prace stanowiły novum w polskiej geografii i w jakimś stopniu uzupełniały lukę w literaturze światowej w zakresie tej dziedziny badań geograficznych.

Poprzez swe intensywne badania nad geograficznymi aspektami zjawisk i procesów religijnych Prof. A. Jackowski stworzył od podstaw nowa w Polsce dyscyplinę nauk geograficznych - geografie religii. Oryginalność Jego prac $z$ tej dziedziny polega m.in. na tym, że poszukuje On miejsca dla badań geograficznych w tak rozległej i bardzo interdyscyplinarnej problematyce, jaka stanowi religia. Prace A. Jackowskiego stały się fundamentem nowocześnie traktowanej geografii religii. W tym zakresie Jego osiagnięcia nie tylko w skali naszego kraju, lecz i w nauce światowej sa nie do przecenienia. Świadczyć o tym moga m.in. liczne cytowania jego prac w wydawnictwach zagranicznych. A. Jackowski znalazł się także w gronie konsultantów Encyklopedii religii $P W N$ (2000-2003), odpowiedzialny za dział z geografii religii. Podsumowaniem jego dotychczasowego dorobku w tej dziedzinie stał się pierwszy $w$ Polsce i jeden $z$ nielicznych na swiecie podręcznik akademicki $z$ geografii religii pt. Święta przestrzeń świata. Podstawy geografui religü (Kraków 2003).

Szczególny przedmiot badań Profesora stanowią migracje pielgrzymkowe zarówno w skali całego świata, jak i Polski. Wśród problemów badawczych podejmowanych w okresie ostatnich kilkunastu lat znalazły się również poszczególne ośrodki kultu religijnego w Polsce. Przede wszystkim chodzi tu o dwa największe i najważniejsze ośrodki polskie, a mianowicie Jasną Górę w Częstochowie oraz Kalwarię Zebrzydowską. Jest bowiem rzeczą paradoksalną, że mimo międzynarodowej rangi tych ośrodków, mimo faktu, że Jasna Góra jest jednym $z$ najważniejszych i największych sanktuariów w świecie chrześcijańskim, zaś Kalwaria Zebrzydowska mieści się w grupie pierwszych dwudziestu ośrodków chrześcijańskich na swiecie - nie doczekały się one wcześniej opracowań związanych $\mathrm{z}$ ich funkcja piel- a sense filled in a gap in world literature on the subject.

Through his intensive research into the geographical aspects of religions, Prof. Jackowski created a new discipline - the geography of religion. The originality of his work is in its attempt to find a place for geography within such a vast and interdisciplinary area. His work has become fundamental to the modern geography of religion and his achievements are invaluable, not only for Poland but beyond and his works are often quoted in foreign publications. Prof. Jackowski has also been responsible as a consultant for the geography of religion section of the The Encyclopaedia of Religion edited by PWN (2002-2003). The best summary of his output so far is a student textbook on the geography of religion, Sacred Spaces in the World: the fundamentals of the Geography of Religion (Krakow 2003), the first such publication in Poland and one of the few in the world.

$\mathrm{He}$ is particularly interested in pilgrimage both in Poland and around the world. Among the research subjects investigated over the last few years have been individual Polish religious cult centres and above all the two largest and most significant: Jasna Góra at Częstochowa and Kalwaria Zebrzydowska. It is a paradox that despite the international importance of these centres, despite the fact that Jasna Gora is one of the largest and most significant sanctuaries in the Christian world, and Kalwaria Zebrzydowska is in the group of the twenty most popular Christian centres in the world - their pilgrimage function had not been described before in such detail. Prof. Jackowski initiated and edited two important monographs in the Peregrinus Cracoviensis series: Traditions, the Present and the Future of Pilgrimages to Kalwaria Zebrzydowska (Kraków 1995), and Jasna Góra: a world pilgrimage centre (Kraków 1996, in both Polish and English versions). They are the first publications concerning both 
grzymkową. Podjęto więc studia $z$ tego zakresu, a ich rezultatem sa publikacje dotyczące Kalwarii Zebrzydowskiej oraz Jasnej Góry. $Z$ inicjatywy Profesora i pod Jego redakcja w serii „Peregrinus Cracoviensis" ukazały się dwie ważące monografie: Tradycje, uspółczesność i przyszłość pielgrzymek $w$ Kalwarï Zebrzydouskiej (Kraków 1995) i Jasna Góra światowe centrum pielgrzymkowe (Kraków 1996, wersje polska i angielska). Sa to pierwsze w literaturze przedmiotu opracowania o tym charakterze dotyczace obu sanktuariów. Wspólnie z D. Ptaszycką-Jackowską opracowal Studium turystyczne Czestochowy w ramach The Phare Transport Study of the Czestochowa City and Region, realizowanego na zlecenie Wspólnot Europejskich w Brukseli (listopad 1996 luty 1997). Efektem tej pracy była książka Jasnogórskie pielgrzymki $w$ przestrzeni miasta $i$ regionu Częstochowy (Kraków 1998, wspólnie z D. Ptaszycka-Jackowska). W latach następnych pod Jego redakcją ukazały się m.in. tomy "Peregrinus Cracoviensis" poświęcone rozwijającemu się Sanktuarium Bożego Miłosierdzia w Krakowie-Łagiewnikach oraz geografii religii. Wyróżniającą się grupą opracowań sa też studia dotyczace Karpat jako wykształconego regionu pielgrzymkowego.

W 1995 r. zakończyła się realizacja pod kierunkiem Prof. A. Jackowskiego projektu badawczego finansowanego przez Komitet Badan Naukowych pt. Przestrzeń $i$ sacrum. Geografia kultury religijnej $w$ Polsce $i$ jej przemiany $w$ okresie XVII-XX $w$. na przyktadzie ośrodków kultu i migracji pielgrzymkowych (PB 0119/P2/92/03). Był on wykonywany w latach 1993-1995 wspólnie $z$ Katolickim Uniwersytetem Lubelskim oraz zakonem oo. paulinów. Było to pierwsze w literaturze polskiej opracowanie o charakterze syntetycznym, dotyczące zjawiska pielgrzymowania - w aspekcie czasowym i przestrzennym - w skali całego kraju. Celem przeprowadzonych badań było określenie zakresu przemian przestrzennych i strukturalnych kultury religijnej w Polsce od schyłku średniowiecza do czasów współczesnych na przykładzie ośrodków kultu i migracji pielgrzymkowych. Ośrodki kultu i pielgrzymki stanowią bowiem jeden $z$ naj- of these sanctuaries. In collaboration with Danuta Ptaszycka-Jackowska, he wrote A Tourist Study of Czestochowa as part of the Phare Transport Study of Czestochowa: city and region, requested by the European Union in Brussels (Nov. 1996 - Feb. 1997). Following this, he wrote Jasna Góra Pilgrimage in the City and Region of Częstochowa (Kraków 1998 with Danuta Ptaszycka-Jackowska) and edited the volume of Peregrinus Cracoviensis devoted to the developing the Sanctuary of Divine Mercy at Kraków-Łagiewniki and to the geography of religion. Another distinctive group of publications are the studies of the Carpathian Mountains as a pilgrimage region.

The research programme space and the sacrum: the geography of religious culture in Poland and its development in the $17^{\text {th }}-20^{\text {th }} c$. - a case study of religious cult centres and pilgrimage (PB 0119/ P2/92/03), financed by the state Academic Research Committee (Komitet Badan Naukowych) and supervised by Prof. Jackowski, was completed in 1995. It had been conducted in 1993-1995 with the Lublin Catholic University and the Order of the Pauline Fathers and was the first in the Polish pilgrimage literature from both temporal and spatial perspectives. Its aim was to define the spatial and structural developments of religious culture in Poland from the late Middle Ages to contemporary times, using examples from religious cult centres and pilgrimage as these form one of the most permanent elements of Polish religious culture. The outcome of the research was the above-mentioned book edited under his supervision in 1995.

Since 1994 when the Geography of Religion Department was established research has been oriented towards the relationship between religion and the natural environment, the religious function and natural and cultural landscape changes, religion and settlement, religion and migration, as well as religion and the economy. Studies are 
bardziej trwałych elementów polskiej kultury religijnej. Efektem końcowym badań była publikacja Przestrzeń $i$ sacrum. Geografia kultury religïnej $w$ Polsce i jej przemiany $w$ okresie od XVII do XX w. na przyktadzie ośrodków kultu i migracji pielgrzymkowych, pod redakcja naukowa Profesora w 1995 r.

Wraz $z$ powstaniem Zakładu Geografii Religii w 1994 r. problematyka badawcza koncentruje się wokół relacji religia-środowisko przyrodnicze, funkcja religijna-przekształcenia krajobrazu naturalnego i kulturowego, religia-osadnictwo, religia-migracje ludności, religia-gospodarka. Prowadzone sa studia dotyczące ośrodków kultu religijnego i migracji pielgrzymkowych w skali krajowej i miedzynarodowej. Dotycza one zwłaszcza problematyki przekształcen w sieci ośrodków pielgrzymkowych w Polsce w aspekcie przestrzenno-czasowym i społeczno-ekonomicznym, ośrodków kultu religijnego na świecie ze szczególnym uwzględnieniem chrześcijaństwa, szlaków wędrówek religijnych, pielgrzymek a turystyki (turystyki religijnej). Częśc $\mathrm{z}$ tych tematów badawczych jest realizowana we współpracy z partnerami zagranicznymi. Zakład posiada wyspecjalizowaną bibliotekę, licząca kilkaset pozycji krajowych i zagranicznych. Rozpoczęto też działania zmierzające do utworzenia w centrum dokumentacji ikonograficznej (rysunki, fotografie, przeźrocza) i filmowej, dotyczącej szeroko pojętej kultury religijnej. Prowadzone sa prace nad kartoteką ośrodków kultu religijnego w Polsce i na świecie.

Prof. A. Jackowski był wielokrotnie zapraszany jako konsultant naukowy przez Urząd Miasta Częstochowy, Urzędy Wojewódzkie w Częstochowie i Krakowie, Sanktuaria na Jasnej Górze, w Kalwarii Zebrzydowskiej oraz $\mathrm{w}$ Tuchowie. Wspólnie $\mathrm{z}$ prezydentem miasta Częstochowy zainicjował Porozumienie Miast Maryjnych Europy, do którego przystapiły w 1996 r. - oprócz Częstochowy - Altötting, Fatima, Lourdes, Loreto.

Do prac o charakterze popularyzatorskim można zaliczyć liczne hasła do słowników, leksykonów i encyklopedii, a także mapy o treści turystycznej i pielgrzymkowej w atlasach regionalnych i ogólnopolskich. Były one publikowane przez władze wojewódzkie, Komisję Nauk Geograficznych conducted, on national and international religious cult centres and pilgrimages, and especially changes in the pilgrimage centre network in Poland spatially, temporally and socio-economically. The research also concerns world religious cult centres with particular attention paid to Christianity, pilgrimage trails, and the relation between pilgrimage and tourism (religious tourism). Some of these issues are studied in collaboration with foreign partners. The department has a library with several hundred Polish and foreign volumes while the first steps have been taken towards creating film and iconographic documentation (drawings, photographs, slides) regarding religious culture. An index of Polish and world religious cult centres is being compiled as well.

Prof. Jackowski has been frequently invited to be a consultant by the City Council of Czestochowa, the Województwo Councils in Częstochowa and Kraków, and the sanctuaries at Jasna Gora, Kalwaria Zebrzydowska and Tuchów. With the President of Czestochowa, he initiated a Union of European Marian cities with Altötting, Fatima, Lourdes and Loretto in 1996.

He has contributed to the popularising of the subject; he is the author of many specialist dictionary and encyclopaedia entries, as well as tourism and pilgrimage maps in atlases of Poland or individual regions. These have been published by Województwo authorities, the Geographical Committee of the Krakow branch of the Polish Academy of Sciences, and the Jagiellonian University Institute of Geography ${ }^{4}$, as well as various other publishers. Prof. Jackowski has reviewed research projects for the Academic Research Committee and foreign organisers, and has reviewed for a variety of publishers (PWN, PWE, university publishers). He has taken part in many national conferences and international congresses. 
Oddz. PAN w Krakowie i Instytut Geografii $\mathrm{UJ}^{4}$ oraz różne wydawnictwa. Był recenzentem projektów badawczych dla Komitetu Badañ Naukowych, projektów zagranicznych, a także recenzentem wydawniczym (PWN, PWE, wydawnictwa uczelniane). Uczestniczył w wielu kongresach międzynarodowych i konferencjach krajowych.

\section{DZIAKALNOŚĆ ORGANIZACYJNA}

Prowadzone badania naukowe, a także działalność dydaktyczna dotycząca problematyki $z$ zakresu geografii religii, stanowity podstawę do wystapienia przez Instytut Geografii UJ z wnioskiem do Rektora UJ o utworzenie w Instytucie odpowiedniej, wyspecjalizowanej komórki w postaci $\mathrm{Za}$ kładu Geografii Religii. Zakład został utworzony zarządzeniem Rektora UJ z 1 czerwca $1994 \mathrm{r}$. Jest to jedyna tego typu placówka w Polsce, druga w Europie (Eichstätt, Niemcy). Od początku kierownikiem Zakładu jest prof. A. Jackowski. W Zakładzie wypracował problematykę badawcza i uruchomił studia empiryczne realizowane przez uczniów, współpracowników i doktorantów.

Również 1994 r. Prof. A. Jackowski zainicjował w Instytucie Geografii UJ środowiskowe i interdyscyplinarne „Konwersatorium Pielgrzymkowe". Celem Konwersatorium była przede wszystkim integracja krakowskiego środowiska naukowego w zakresie badan szeroko pojętej kultury religijnej, a szczególnie ośrodków kultu i pielgrzymek. Wykłady prezentowali badacze $z$ różnych placówek naukowych (swieckich i kościelnych) Krakowa, a póżniej $z$ całej Polski. Teksty wykładów publikowane były w periodyku „Peregrinus Cracoviensis”. „Konwersatorium" funkcjonowało do końca 2001 r.

Sukcesem organizacyjnym Prof. A. Jackowskiego było również utworzenie w Instytucie Geografii i Gospodarki Przestrzennej UJ oryginalnego periodyku naukowego pt. „Peregrinus Cracoviensis”. Zaczą się on ukazywać pod Jego redakcją od 1995 r. Do końca 2004 r. ukazało się łącznie 15 zeszytów. Jest to jedyne tego typu czasopismo w Europie. Obejmuje problematykę z zakresu szeroko rozumianej geografii religii, szczególnie zaś pielgrzymowania. Periodyk

\section{THE ORGANISER}

On the basis of his academic research and educational activity in the field of the geography of religion, the Jagiellonian University Institute of Geography applied to the Rector for permission to create a specialised Geography of Religion Department. This was established on 1 June 1994 and is the only institution of its kind in Poland, while being the second in Europe (following Eichstätt, Germany). From the very beginning the Department has been run by Prof. Jackowski who has established its research emphases and initiated empirical studies by undergraduates, post-graduate students and colleagues.

In the same year Prof. Jackowski started an interdisciplinary 'Pilgrimage Seminar' (Konwersatorium Pielgrzymkowe) at the Geography Institute whose aim above all was to integrate Kraków academic circles concerning culture and religion (especially religious cult centres and pilgrimage). Lectures were delivered by academics from different institutions in Kraków (both secular and ecclesiastical), and later from all parts of Poland. The lectures were published in the journal Peregrinus Cracoviensis and the seminar functioned until the end of 2001.

The creation of the journal Peregrinus Cracoviensis has been a considerable organisational success at the Institute of Geography and Spatial Economy, with the first issue appearing in 1995 and followed by 15 more by the end of 2004 . It is the only journal covering the problems of the geography of religion, and pilgrimage in particular, in Europe; it is interdisciplinary and increasingly presents the work of foreign authors.

In 1995 (Nov.-Dec.) in Czestochowa he organised an exhibition Polska Pielgrzymujaca (Pilgrimage Poland) a part of the 'International Forum for Religious Cult Centres' with the City Council and Regional Museum of Częstochowa. It was the first academic exhibition of this kind in Poland and probably in Europe as well showing maps, graphs and tables to present Polish pilgrimage in 
ma charakter interdyscyplinarny. Coraz częściej wśród autorów pojawiają się nazwiska zagraniczne.

W 1995 r. (listopad-grudzień) w Częstochowie miała miejsce wystawa autorska Prof. A. Jackowskiego pt. Polska pielgrzymujaca, która towarzyszyła Międzynarodowemu Forum Ośrodków Kultu Religijnego. Została ona zorganizowana przez Urzad Miasta Częstochowy oraz Muzeum Regionalne w Częstochowie. Była to pierwsza tego typu wystawa naukowa w Polsce, a zapewne i w Europie. Eksponowane były przede wszystkim mapy, wykresy, tabele pokazujace miejsce pielgrzymek $\mathrm{w}$ Polsce $\mathrm{w}$ migracjach pielgrzymkowych na świecie (nie tylko w chrześcijaństwie). Szczególnie eksponowana była Jasna Góra. Wystawę obejrzało około tysiąca osób z Polski i z zagranicy.

W czasie swojej pracy w Instytucie Geografii i Gospodarki Przestrzennej Prof. Antoni Jackowski pełnił lub pełni obecnie następujące funkcje:

- kierownik studiów zaocznych w Instytucie Geografii UJ (1973-1982),

- zastępca dyrektora Instytutu Geografii UJ ds. dydaktycznych (1984-1987),

- prodziekan Wydziału Biologii i Nauk o Ziemi UJ ds. studenckich (1987-1990),

- dyrektor Instytutu Geografii UJ (19911993 i ponownie od 1999),

- dziekan Wydziału Biologii i Nauk o Ziemi UJ (1993-1999),

- kierownik Zakładu Geografii Religii w Instytucie Geografii UJ (od 1994 r.),

- pełnomocnik Rektora UJ ds. współpracy $z$ Uniwersytetem Blaise-Pascal w Clermont-Ferrand, Francja (1984-1994),

- przewodniczący Rady Fundacji im. Stanisława Estreichera (2000-2004),

- członek Senatu UJ (1981-1984 i od 1993 r.),

- od wielu lat czlonek wielu komisji senackich, rektorskich i wydziałowych.

\section{DZIAłALNOŚĆ DYDAKTYCZNA}

Prof. dr hab. Antoni Jackowski jest doświadczonym i zasłużonym nauczycielem akademickim. Prowadził wszystkie typy zajęc dydaktycznych. Wykładał geografię religii na Uniwersytetach w Rzymie, Clermont - a context of world pilgrimages (not only for Christianity). Jasna Góra was particularly well presented and the exhibition was visited by about 1000 people from Poland and abroad.

Over the time Prof. Jackowski has been working at the Institute of Geography and Spatial Economy, he has held the following posts:

- Director of Extra-mural Studies at the Jagiellonian University Institute of Geography (1973-1982);

- Institute of Geography Deputy Director with responsibility for teaching (1984-1997);

- Vice-Dean of the Department of Biology and Earth Sciences at the Jagiellonian University (1987-1990);

- Geography Institute Director (19911993, and again from 1999);

- Dean of the Department of Biology and Earth Sciences (1993-1999);

- Director of the Geography of Religion Department at the Institute of Geography (from 1994);

- Authorised by the Jagiellonian University Rector to be responsible for cooperation with the Blaise-Pascal University in Clermond-Ferrand, France (1984-1994);

- Chairman of the Stanisław Estreicher Foundation Council (20002004);

- University Senate member (19811984 and from 1993);

- For many years a member of numerous Senate, Rectoral and Departmental Committees.

\section{THE TEACHER}

Prof. Antoni Jackowski is an experienced academic teacher with many awards. He has conducted all types of classes and given lectures on the geography of religion at universities in Rome, Clermont-Ferrand and Basle, as well as for students of geography and other departments, on socio-economic geography, the geography of tourism and the geography of religion. He has supervised over 160 MA theses in geography and nearly 30 
-Ferrand i Bazylei. Prowadzil wszystkie typy zajęć dla studentów geografii i innych kierunków w zakresie geografii społeczno-ekonomicznej, geografii turyzmu oraz $\mathrm{z}$ geografii religii. Pod jego kierunkiem uzyskato dyplom magistra ponad 160 studentów geografii oraz blisko 30 studentów religioznawstwa. Współuczestniczył w staraniach o utworzenie w Instytucie Geografii UJ pierwszej w Polsce specjalności $z$ geografii turyzmu (uruchomiona od 1977 r.) i w przygotowaniu dla niej programu studiów. Od 2002 r. jest opiekunem naukowym studentów na Międzywydziałowych Indywidualnych Studiach Humanistycznych UJ. Od 1995 r. prowadzi seminarium doktoranckie $z$ geografii religii. Opiekował się trzema habilitantami. Wypromowal trzech doktorów. Pięć dalszych osób ma otwarty przewód doktorski. Był recenzentem $\mathrm{w}$ trzech przewodach profesorskich, pięciu habilitacyjnych, ośmiu doktorskich, a także wniosków o stanowiska profesorów zwyczajnych i nadzwyczajnych. Był inicjatorem oraz współorganizatorem Podyplomowego Studium „Pielgrzymki. Turystyka Religijna”, utworzonego w 1995 r. wspólnie przez Instytut Geografii UJ, Jasną Górę oraz Wyższą Szkołe Języków Obcych i Ekonomii (obecnie Akademia Polonijna) w Częstochowie.

\section{CZŁONKOSTWO W TOWARZYSTWACH NAUKOWYCH ZA GRANICA I W KRAJU. KOMITETY REDAKCYJNE. NAGRODY I WYRÓŻNIENIA}

Aktywna postawa naukowa oraz ogromna wiedza Profesora została dostrzeżona i doceniona. W 1996 r. A. Jackowski został mianowany przez Jana Pawła II członkiem czteroosobowej tzw. „Misji Papieskiej”, reprezentującej Ojca Świętego w czasie Międzynarodowego Kongresu Maryjnego w Częstochowie (sierpien 1996 r.). W 1997 r. powołano Go na członka korespondenta Papieskiej Międzynarodowej Akademii Mariologicznej w Rzymie. Jest jednym $z$ nielicznych członków świeckich i jedynym geografem.

W latach 1991-1993 był przedstawicielem Polski w Komisji ds. Europejskich in the study of religion. He had been one of those who fought for the opening of the first Polish geography of tourism specialisation at the Jagiellonian University Institute of Geography (opened in 1977), and for preparing its curriculum. Since 2002 he has been an academic supervisor to students doing 'Interdepartmental Humanistic Studies', at the Jagiellonian University. Since 1995 he has been conducting a post-graduate seminar in the geography of religion, supervised three habilitation theses and three PhD students with a further five having started work on their PhDs under his supervision. He has been a reviewer of eight doctoral, five habilitation and three docent theses, as well as of applications for the positions of 'university' and 'full' professors. He was the initiator and co-organiser of the 'Pilgrimage and Religious Tourism' a postgraduate research unit established in 1995 by the Institute of Geography, Jasna Gora and the College of Foreign Languages and Economics (currently the Polonia Academy) in Częstochowa.

\section{MEMBERSHIP OF POLISH AND FOREIGN ACADEMIC ASSOCIATIONS, EDITORIAL BOARDS COMMITTEES, AWARDS AND DISTINCTIONS}

His academic activity and his vast knowledge have been noticed and appreciated. In 1996 Pope John Paul II appointed Antoni Jackowski as one of a four-member 'Papal Mission' representing the Pope during the International Marian Congress in Czestochowa (August 1996). In 1997 he was nominated a corresponding member of the 'International Papal Academy of Mariology' in Rome. He is one of the few secular members and the only geographer among them.

From 1991-1993 he represented Poland on the 'Committee for European Cultural Routes' at the Council of Europe, working on European monastic and pilgrimage routes. From 1973-1993 he was a corresponding member of the Geography of Tourism and Leisure Commission at the 
Szlaków Kulturowych Rady Europy, opracowując europejskie szlaki monastyczne i pielgrzymkowe.

W latach 1973-1993 był członkiem korespondentem International Geographical Union, Commission of Geography of Tourism and Leisure. Brał czynny udział w pracach Komisji, m.in. w problemie Stacje sportów zimowych na świecie (wspólnie z J. Warszyńska). Od 1987 r. jest członkiem korespondentem International Working Group on the Geography of Belief Systems. W ramach Grupy nawiazał kontakty naukowe $\mathrm{z}$ geografami szeregu krajów, którzy prowadza badania z zakresu geografii religii. Od 1989 r. jest członkiem Society of Pilgrimages Studies (Allahabad, Indie) oraz zostal powołany do 10-osobowego grona Corresponding Editors periodyku Towarzystwa „Bulletin of the Society of Pilgrimages Studies". Ponadto jest członkiem Komitetu Nauk Geograficznych PAN (od 1984 r.), a od 2003 r. członkiem jego Prezydium. Działa także w Komisji Nauk Geograficznych PAN Oddz. w Krakowie (od 1987 r.), w Polskim Towarzystwie Geograficznym (od 1960 r.) oraz jest członkiem Rady Naukowej (1993-1999) Międzywydziałowego Zakładu Studiów Europejskich UJ. Pełnił także funkcje sekretarza redakcji "Zeszytów Naukowych UJ, Prace Geograficzne", Seria Geografia Ekonomiczna (1980-1991). Był członkiem Komitetu Redakcyjnego kwartalnika „Ruch Turystyczny" (SGPiS-SGH Warszawa, 19791990), Rady Programowej kwartalnika UJ „Alma Mater” (1993-1999), Rady Programowej Centrum Edukacji Kadr Turystycznych (od 1997 r.), Sekcji P04E przy Zespole P-4 KBN (2000-2003) oraz ekspertem Państwowej Komisji Akredytacyjnej (2003), Przewodniczacym Konferencji Kierowników Geograficznych Jednostek Uczelnianych (od 2002) i członkiem Komitetu Narodowego ds. Współpracy z Międzynarodową Unią Geograficzna (od 2003), Komitetu Redakcyjnego czasopisma „Turyzm” (Uniwersytet Łódzki), Komitetu Redakcyjnego periodyku „Folia Geographica” Uniwersytetu w Prešowie (od 2002 r.), Komitetu Redakcyjnego "Studiów Geograficznych" Uniwersytetu
International Geographical Union. He took an active part in the Commission's ventures such as Winter sport resorts around the world (in cooperation with Prof. Warszynska). Since 1987 he has been a corresponding member of the International Working Group on the Geography of Belief Systems. Being part of this group he made contacts with geographers conducting research into the geography of religion from many countries. Since 1989 he has been member of the Society of Pilgrimage Studies (Allahabad, India), as well as one of ten Corresponding Editors of the society's periodical Bulletin of the Society of Pilgrimage Studies. Moreover, he has been a member of the PAN (Polish Academy of Science) Geographical Committee (since 1984), and a member of its presiding body since 2003 . He has also been active in the Krakow branch of the PAN Geography Commission (since 1987), the Polish Geographical Society (since 1960), and a member of the 'Academic Council' (1993-1999) of the Interdepartmental European Studies Department at the Jagiellonian University. Prof. Jackowski was also the editorial secretary of Zeszyty Naukowe UJ, Prace Geograficzne and Seria Geografia Ekonomiczna (19801991), a member of the editorial committee of the quarterly Ruch Turystyczny (SGPiSSGH Warsaw, 1979-1990), the editorial committee of Turyzm (University of Łódż), the editorial committee of Folia Geographica at the University of Prešov (since 2002), Studia Geograficzne at the University of Wroclaw, Prace Geograficzne at the Jagiellonian University, a member of the 'Programme Council' of Alma Mater - the Jagiellonian University quarterly (19931999), of the 'Programme Council' of the Tourist Service Education Centre (since 1997), PO4E section of the P-4 KBN Group (2000-2003), as well as a 'State Accreditation Commission' expert (2003), the Chairman of the 'Directors of University Geography Departments Conference' (since 2002), and a member of the National Committee for Cooperation with the International Geographical Union (since 2003).

Prof. Antoni Jackowski has been given awards by the National Ministry of Educa- 
Wrocławskiego, Komitetu Redakcyjnego „Prac Geograficznych” Uniwersytetu Jagiellońskiego.

Prof. Antoni Jackowski jest laureatem nagród Ministra Edukacji Narodowej oraz Rektora Uniwersytetu Jagiellońskiego. Został odznaczony Krzyżem Kawalerskim Orderu Odrodzenia Polski (2002), Złota Odznaka Polskiego Towarzystwa Geograficznego (1998), odznaka „Zasłużony dla Rozwoju Województwa Częstochowskiego" (1998) oraz „Zasłużony Działacz Turystyki” (1971). Od 1993 r. należy do Rycerstwa Orderu Jasnogórskiej Bogarodzicy.

Prof. Antoni Jackowski należy do wąskiego grona polskich geografów, którzy wytyczyli nowe, oryginalne pole badawcze w geografii (geografia turyzmu, geografia religii), określając przedmiot i zakres jego badan, opracowując odpowiednią metodologię badań, a co może najważniejsze wykonujac szereg prac empirycznych, dokumentujących przydatnośc swoich przemyśleń i dociekań teoretycznych. Należy do nielicznej w Polsce grupy geografów najbardziej twórczych zarówno badawczo, jak i organizacyjnie.

Wielka aktywność Prof. Antoniego Jackowskiego na polu badawczym, organizacyjnym i dydaktycznym sprawiła, że osobiście sam Profesor, ale również geograficzny ośrodek krakowski (Instytut, Zakład), znany jest powszechnie - zarówno w Polsce, jak też w Europie, Ameryce Północnej i w niektórych krajach azjatyckich (m.in. Indie, Japonia) - jako centrum badawczo-dydaktyczne geografii religii i geografii turyzmu.

\section{PRZYPISY}

${ }^{1} \mathrm{Na}$ wniosek wydawnictwa PWN podręcznik ten zostal wyróżniony nagrodą zespolowa Ministra NSzWiT II stopnia (1979 r.).

2 Za pracę te otrzymał nagrodę Ministra NSzWiT III stopnia (1984 r.).

${ }^{3}$ Za obie prace uzyskal nagrodę indywidualna Ministra Edukacji Narodowej (1992 r.).

${ }^{4}$ Za współudzial w opracowaniu Atlasu miasta Krakowa otrzymal nagrode zespołowa Ministra Edukacji Narodowej I stopnia (1989 r.). tion and the Rector of the Jagiellonian University. He has received the Krzyz $\mathrm{Ka}^{-}$ walerski Orderu Odrodzenia Polski (2002) a very high award for services to Poland, the gold medal of the Polish Geographical Society (1998), the Zastużony dla Rozwoju Województwa Czestochowskiego (a medal for services to the development of Czestochowa Wojewódzwo) (1998) and the Zastużony Dziatacz Turystyki medal for contributions to the development of tourism (1971). Since 1993 he has belonged to the Knighthood of the Order of the Mother of God at Jasna Góra (Rycerstwo Orderu Jasnogórskiej Bogarodzicy).

He belongs to the small group of Polish geographers who have established new and original research fields in geography (the geography of tourism and the geography of religion), defining their subjects and range of study, establishing an appropriate research methodology and, what is most important, doing a number of empirical studies to demonstrate the usefulness of the theoretical research. He is one of the most creative Polish geographers both as a researcher and as an organiser.

The remarkable activity of Prof. Antoni Jackowski has made him famous and with it the Krakow geographical centre (both the Institute and the Department) as a wellknown research and teaching centre for the geography of religion and geography of tourism, not only in Poland but also in Europe, North America and some Asiatic countries (e.g. India and Japan).

\section{NOTES}

1 At the recommendation of the Publishers PWN the book was given a 'collective' award by the Minister of Sport and Recreation (1979).

2 This work received the Minister of Sport and Recreation's Award (1984).

3 For both works he received an individual award from the Minister of National Education (1992).

4 For his contributions to the Atlas of the City of Krakow, he received a 'collective' award from the Minister of National Education (1989). 